Original Research

\title{
Effects of Nutrition on Wheat Photosynthetic Pigment Responses to Arsenic Stress
}

\author{
Marína Maglovski', Zuzana Geršìi, L’ubomír Rybanskýz, Monika Bardáčová2, \\ Jana Moravčíková ${ }^{6}$, Marek Bujdoš ${ }^{4}$, Anelia Dobrikova ${ }^{5}$, Emilia Apostolova ${ }^{5}$, \\ Ján Kraic ${ }^{6}$, Alžbeta Blehová7, Ildikó Matušíková2
}

\author{
${ }^{1}$ Institute of Plant Genetics and Biotechnology, Plant Science and Biodiversity Center SAS,Nitra, Slovak Republic \\ ${ }^{2}$ Department of Ecochemistry and Radioecology, Faculty of Natural Sciences, University of Ss. Cyril \\ and Methodius in Trnava, Trnava, Slovak Republic \\ ${ }^{3}$ Department of Mathematics, Faculty of Natural Sciences, Constantine the Philosopher University, \\ Nitra, Slovak Republic \\ ${ }^{4}$ Institute of Laboratory Research on Geomaterials, Faculty of Natural Sciences, Commenius \\ University in Bratislava, Bratislava, Slovak Republic \\ ${ }^{5}$ Institute of Biophysics and Biomedical Engineering, Bulgarian Academy of Sciences, Sofia, Bulgaria \\ ${ }^{6}$ Department of Biotechnology, Faculty of Natural Sciences, University of Ss. Cyril and Methodius in Trnava, \\ Trnava, Slovak Republic \\ ${ }^{7}$ Department of Plant Physiology, Faculty of Natural Sciences, Comenius University in Bratislava, \\ Bratislava, Slovak Republic
}

Received: 12 February 2018

Accepted: 27 March 2018

\begin{abstract}
Arsenic is a serious soil pollutant with toxic effects on biological systems. Elevated soil concentrations may negatively affect crop production and food safety. The impact of arsenic on plants depends on many factors, including nitrogen availability. Nitrogen $(\mathrm{N})$ as an essential mineral affects overall energetics of plants, while its non-optimal doses have been shown to also impact plant performance and yield, as well as tolerance to environmental constraints. The combined effects of these two factors, however, have been rarely studied. Here we investigated the impact of sublethal doses of $\mathrm{As}^{3+}(5 \mathrm{mM})$ on wheat plants grown in hydropony, applying a set of 8 different $\mathrm{N}$ concentrations spanning from starvation ( $0 \mathrm{mM} \mathrm{N}$ in the media) through optimum $(7.5 \mathrm{mM} \mathrm{N}$ ) to excessive amounts (up to $35 \mathrm{mM} \mathrm{N}$ ). The results showed that the content of photosynthetic pigments varies depending on $\mathrm{N}$ concentration and $\mathrm{As}^{3+}$ presence. The different energetic status of plants also affected the final As uptake. Establishing nutrition conditions might be important for limiting metal(loid) uptake from soil in contaminated areas.
\end{abstract}

Keywords: arsenic, chlorophylls, defense trade-off, metalloid, nitrogen

*e-mail: zuzana.gregorova@ucm.sk 


\section{Introduction}

Arsenic (As) as a toxic environmental pollutant exerts a negative effect on plant growth and development [1-3]. Continual accumulation of As in soil over time could lead to phytotoxic soil concentrations, leading to a reduction in yields and other negative impacts. Elevated soil concentrations may negatively affect crop production and food safety, while harmful effects of As on plants are directed toward chlorophyll, carotenoid and protein contents, and antioxidant enzyme activities, and cause toxicity leading to perturbation of various physiological and biochemical functions [1-2, 4-5]. Arsenic also seems to disrupt $\mathrm{N}$ assimilation [5]. Cao et al. [6] argue that at lower doses, arsenic may be relatively less toxic or even have a stimulating effect on plant growth. At higher concentrations, however, it interferes with the metabolic processes in tissues when it prevents growth and subsequently causes the plant to die [1-2]. If accumulated in the edible parts, arsenic may pose a human health risk.

The response to environmental cues (including metal toxicity) is regulated in plants through coordinated uptake and distribution of nutrients [7]. It is therefore imperative to study the adaptation mechanisms to nonoptimal nitrogen $(\mathrm{N})$ availability in crops, as these are key to coping with both $\mathrm{N}$ starvation and a surplus of $\mathrm{N}$ fertilizer supply. While the former causes low plant performance leading to yield losses, the overuse of $\mathrm{N}$ fertilizers has become a serious issue worldwide in recent decades, causing a series of environmental and economic problems. It is well known that nitrogen shortage impairs photosynthesis and limits plant growth, affecting the synthesis of nucleic acids and enzymes [8]. However, nutrition supply exceeding $10 \mathrm{mM}$ nitrate generally hinders plant growth, too, while a $25 \mathrm{mM}$ dose is considered the threshold of toxicity for some species [9 and therein]. Thus, sub- as well as supra-optimal nitrogen doses evoke stress conditions for plants and lead to re-modelling of plant metabolism. Considering that performance of the plant defense is costly, contrasting nutrition availability essentially predisposes the plants to distinct adaptive reaction and defense. There are several theories trying to explain how plants can handle the cost-benefit trade-offs during defense [for reviews see, e.g., 10]; however, none of them fits perfectly to all occurring scenarios through different mechanisms. For example, constitutive defense components such as various phenolic compounds were generally more strongly expressed under N-limiting conditions, while observations indicated variable correlations with $\mathrm{N}$ supply for other compounds such as terpenes or alkaloids [ 9 and therein]. Few studies have reported on inducible defense components responsive to nutrient availability. A positive correlation with excessive $\mathrm{N}$ was found for the activity of chitinases [8-9] and peroxidases [9]. More recently, several highthroughput studies have focused on plant responses to different fertilizer regimes [11-13], and some identified that defense-related enzymes such as chitinases respond to unfavorable $\mathrm{N}$ doses [14]. The number of studies dealing with combined effects of nutrition and metal stress, however, remains limited. Here, the effects of nutrition on wheat responses to As-stress were investigated. We analyzed some parameters of growth and the accumulation of proline as a typical plant defense metabolite under stress and a good indicator of $\mathrm{N}$ excess [14]. As almost all of the adverse effects of arsenic on physiological parameters are related to the basic photochemical reaction in plants, photosynthesis, we measured the contents of chlorophyll $a$ and $b$, the major photosynthetic pigments in leaves, to justify their correlations with plant growth and performance under various nutrition conditions.

\section{Material and Methods}

Plant Material, Cultivation,
and Experimental Design

Wheat seeds (Triticum aestivum cv. Genoveva) were surface-sterilized with $5 \%(\mathrm{v} / \mathrm{v}) \mathrm{NaOCl}$ for $15 \mathrm{~min}$, washed 3 times with sterile water, and pre-germinated in Petri dishes on moist filter paper for two days. Uniformly germinated seeds $(15$, roots ca. $1.5 \mathrm{~cm})$ were grown under hydroponic conditions in plastic containers $(15 \times 15 \times 20 \mathrm{~cm}$; 15 plants per container $)$ with $700 \mathrm{ml}$ of

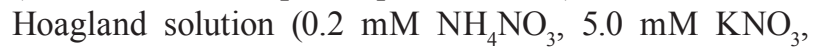
$2.0 \mathrm{mM} \mathrm{Ca}\left(\mathrm{NO}_{3}\right)_{2}, 2.0 \mathrm{mM} \mathrm{MgSO}{ }_{4}, 0.5 \mathrm{mM} \mathrm{Na} \mathrm{SiO}_{3}$, $0.1 \mathrm{mM} \mathrm{KH}_{2} \mathrm{PO}_{4}, 50 \mu \mathrm{M}$ NaFe(III)EDTA, $50 \mu \mathrm{M}$ $\mathrm{H}_{3} \mathrm{BO}_{3}, 5 \mu \mathrm{M} \mathrm{MnCl}_{2}, 5 \mu \mathrm{M} \mathrm{ZnSO}_{4}, 0.5 \mu \mathrm{M} \mathrm{CuSO}_{4}$, and $0.1 \mu \mathrm{M} \mathrm{Na} \mathrm{MoO}_{3}$ ). The nitrogen content was modified so that $\mathrm{KNO}_{3}$ was replaced with $\mathrm{K}_{2} \mathrm{SO}_{4}$ and $\mathrm{Ca}\left(\mathrm{NO}_{3}\right)_{2}$ with $\mathrm{CaCl}_{2}$, and nitrogen was supplemented in the form of $\mathrm{NH}_{4} \mathrm{NO}_{3}$ to achieve final concentrations of $0,0.75$, $5.25,7.5,15,25,30$, and $35 \mathrm{mM} \mathrm{N}$. To a parallel set of containers, $5 \mathrm{mM} \mathrm{As}^{3+}$ (in a form of $\mathrm{As}_{2} \mathrm{O}_{3}$ solution) was added. The containers were constantly aerated and cultivated in a growth chamber at $18^{\circ} \mathrm{C}$ between 06:00 and 18:00 and $22^{\circ} \mathrm{C}$ between $06: 00$ and 18:00. Relative humidity was $60 \%$ with a $16 / 8 \mathrm{~h}$ photoperiod, and irradiance ranging from 300 to $400 \mu \mathrm{mol} \mathrm{m}^{-2} \mathrm{~s}^{-1}$ of PAR. Early stage plants (Feeks stage 3, $10 \mathrm{~cm}$ ) were sampled and analyzed individually after 10 days of growth. The experiment in a randomized complete block design was performed 9 times.

\section{Assays of As Content}

The dried shoots $(0.5 \mathrm{~g})$ were dissolved in a mixture containing $5 \mathrm{ml}$ of water, $5 \mathrm{ml}$ of concentrated $\mathrm{HNO}_{3}$, and $1.5 \mathrm{ml}$ of $\mathrm{H}_{2} \mathrm{O}_{2}$ using an Anton Paar Multiwave 3000 microwave system. The volume of the solution was filled up to $25 \mathrm{ml}$ with deionized water and filtered through an acid-resistant cellulosic filter (Whatman No. 42). Assay was performed by inductively coupled plasma mass spectrometry on a Perkin Elmer Elan 
6000. The procedure was verified using two certified reference plants: NCS DC73349 $(1.25 \pm 0.15 \mu \mathrm{g} / \mathrm{g} \mathrm{As})$ and NCS DC73350 (0.37 $\pm 0.09 \mu \mathrm{g} / \mathrm{g}$ As) (China).

\section{Assays of Photosynthetic Pigment Content and Lipid Peroxidation Rate}

Growth rate was determined by measurements of length of both shoots and roots. The content of assimilation pigments in 8-10 leaves per container was determined in acetone extracts of $50 \mathrm{mg}$ of fresh tissue according to Lichtenthaler and Wellburn [15]. The measured parameters were: chlorophylls (Chl a, Chl b), total chlorophylls (Chl $(a+b))$, chlorophylls ratio $(\mathrm{Chl} a / b)$, total carotenoids (Car), and ratio (Chl $(a+b) / C a r)$. The data from individual containers were averaged to represent a biological replicate.

The ongoing oxidative stress was assayed. Accumulation of hydrogen peroxide with diaminobenzene (DAB) was detected histochemically [16]. The level of malondialdehyde (MDA) in shoot tips (100 $\mathrm{mg}$ fresh weight) was determined
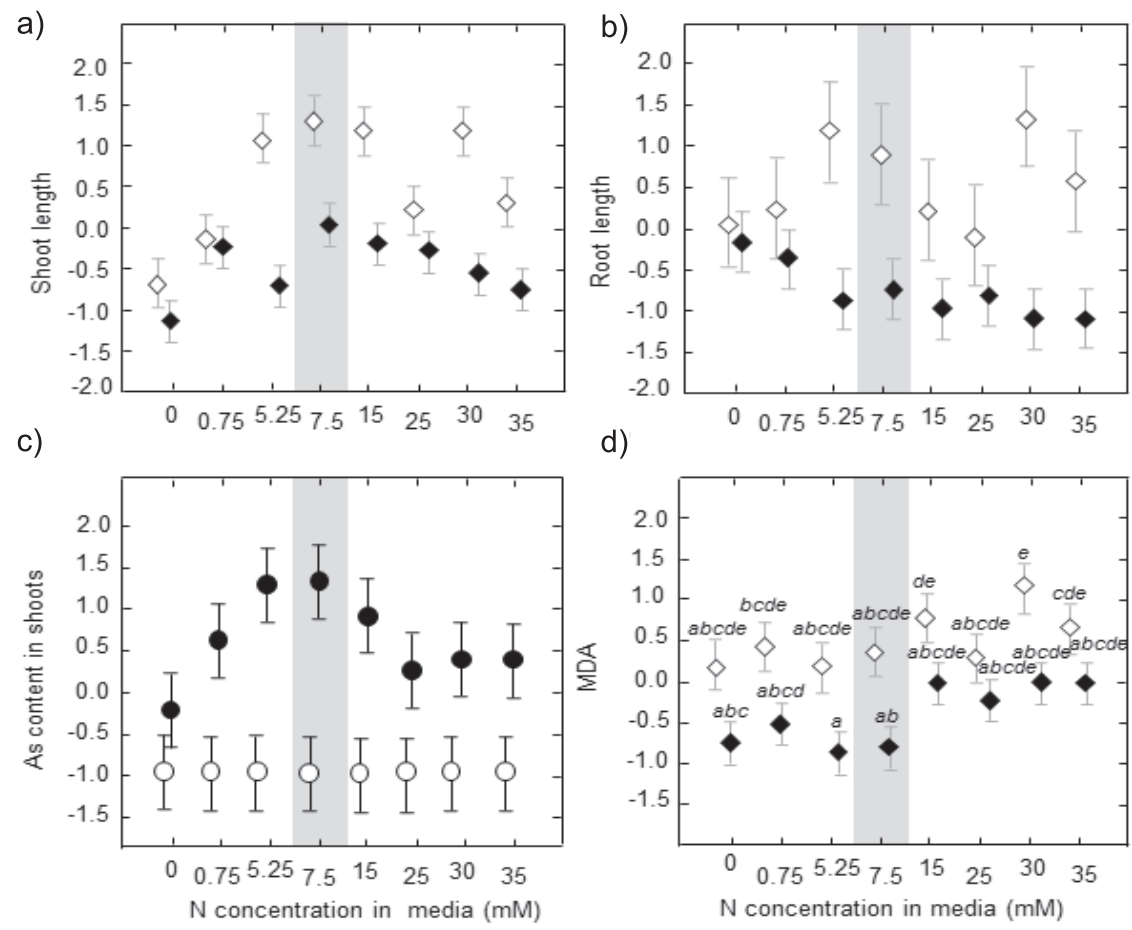

e)
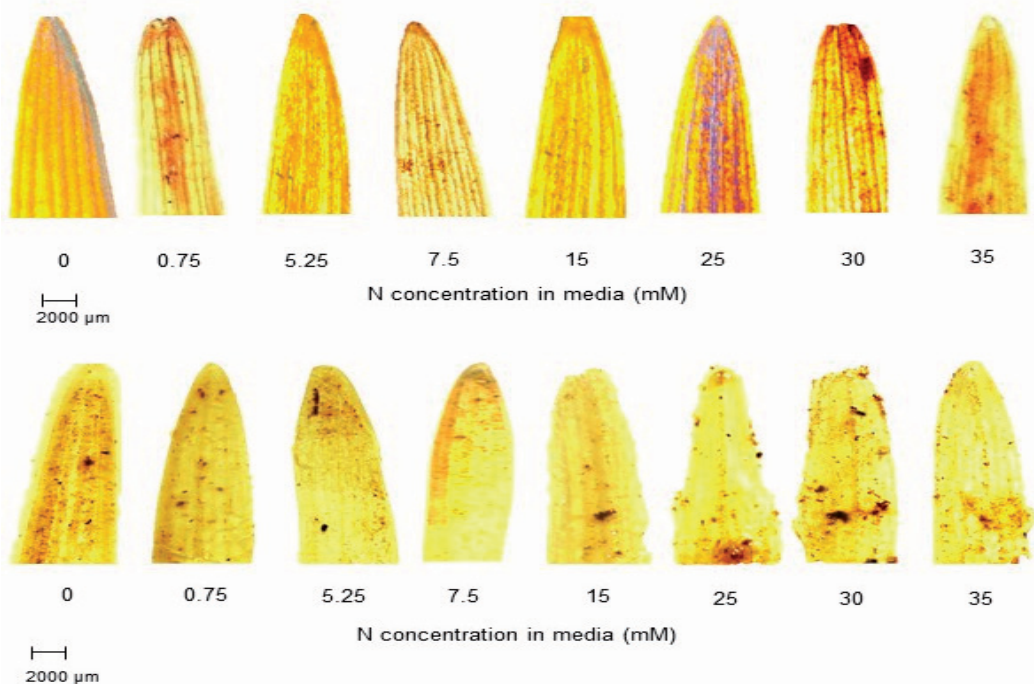

5.25

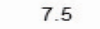

15

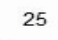

30

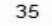

$\mathrm{N}$ concentration in media $(\mathrm{mM})$
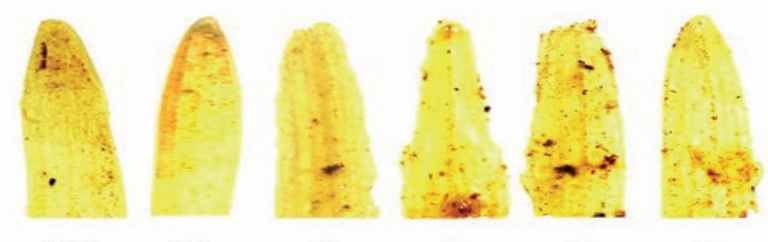

$\mathrm{N}$ concentration in media $(\mathrm{mM})$

25

30

35

Fig. 1. Impact of different $\mathrm{N}$ concentrations in growth media (in $\mathrm{mM}$ ) on wheat plants at growth in absence (empty symbols) or presence (filled symbols) of $5 \mathrm{mM} \mathrm{As}^{3+}$. Presented are data on shoot length a), root length b), content of As in the shoot tissue c), as well as level of malondialdehyde (MDA) as an indicator of membrane peroxidation level d). Hydrogen peroxide formed brown precipitates with diaminobenzidine under certain conditions e). The data represent standardized average values with $95 \%$ confidential intervals ( $\mathrm{n}=4$ for $\mathrm{a}, \mathrm{b}, \mathrm{d}$, and $\mathrm{n}=3$ for $\mathrm{c})$. Different letters indicate significance at $\mathrm{P}<0.05$. 
Table 1. Effects of arsenic presence (As) and/or nitrate content (N) on MDA content.

\begin{tabular}{|c|c|c|c|c|c|c|c|c|c|}
\hline & \multicolumn{3}{|c|}{ Effect of As } & \multicolumn{3}{c|}{ Effect of N } & \multicolumn{3}{c|}{ Effect of N x As } \\
\hline Parameter & $\mathrm{F}$ & $\mathrm{D}_{\mathrm{f}}$ & $\mathrm{P}$ & $\mathrm{F}$ & $\mathrm{D}_{\mathrm{f}}$ & $\mathrm{P}$ & $\mathrm{F}$ & $\mathrm{D}_{\mathrm{f}}$ & $\mathrm{P}$ \\
\hline Content of MDA_roots & 6,49 & 1 & $<0,001$ & 648,72 & 7 & $<0,001$ & 10,75 & 7 & $<0,001$ \\
\hline Content of MDA_shoots & 39,29 & 1 & $<0,001$ & 3,02 & 7 & $=0,005$ & 0,45 & 7 & $=0,871$ \\
\hline
\end{tabular}

$\mathrm{F}$ - two-factor dispersion analysis

$\mathrm{D}_{\mathrm{f}}$ - degree of freedom

$\mathrm{P}$ - significance level

spectrophotometrically by the thiobarbituric acid assay with molar extinction coefficient $155 \times 10^{5} \mathrm{mM}^{-1} \mathrm{~cm}^{-1}$ [17].

\section{Analyses of Proline}

Free proline content in leaf tips $(\sim 1 \mathrm{~cm}$ long, a total of $200 \mathrm{mg}$ fresh weight) was quantified spectrophotometrically at $515 \mathrm{~nm}$ using a standard curve. For proline-related gene expression analyses, genes for proline synthase (P5CS) and ornithine amino transferase $(O A T)$ were analysed using published primer pairs: Ta_P5CS:

\section{GCACCCTCGAATTTGTTGATG/}

ACAATCTGTGTGTGCACTTCCAT,

\section{Ta_OAT: GGCACGGAGGCAAATGAG/}

AGTGAAATAATGTCATGGGAACCA.

The cDNA from $1 \mu \mathrm{g}$ RNA [18] was isolated with the Maxima H Minus First Strand cDNA Synthesis Kit and OligodT primers (Thermo Scientific). The gene for $\beta$-tubulin (U76895) was used for normalization. The reaction mixtures contained $5 \mu \mathrm{l} 2 \mathrm{X}$ SYBR Green PCR Master Mix (Life Technologies), $0.3 \mu \mathrm{l} 10 \mu \mathrm{M}$ of both forward and reverse gene specific primers, nucleasefree water, and $1 \mu 1$ 1:3 diluted cDNA. The qPCR was carried out in LightCycler Nano (Roche) real-time PCR system in a duplicate in 8-well PCR strips. The PCR programme was as follows: $50^{\circ} \mathrm{C}$ for $2 \mathrm{~min}$, followed by denaturation at $95^{\circ} \mathrm{C}$ for $10 \mathrm{~min}$. A thermal cycling profile of $95^{\circ} \mathrm{C}$ for $10 \mathrm{~s}$ and $60^{\circ} \mathrm{C}$ for $30 \mathrm{~s}$ was performed 45 times. A melting curve was recorded by holding at $95^{\circ} \mathrm{C}$ for $10 \mathrm{~s}$, cooling to $60^{\circ} \mathrm{C}$, and then heating at $0.1^{\circ} \mathrm{C} / \mathrm{s}$ up to $95^{\circ} \mathrm{C}$. The amplification and melting curve data were collected and analyzed using LightCycler Nano software 1.0.

\section{Statistical Analyses}

Two-way ANOVA was performed to test the effects of arsenic and nitrogen concentration on the tested parameters. Multiple comparisons were performed using a Tukey post hoc test. The relationship between the parameter values was examined using a Spearman correlation coefficient. The statistical analyses were conducted with the statistical package STATISTICA 8 (StatSoft Inc. 2007). For transparent presentation of results, the data for individual parameters were standardized $(z)$ as $\mathrm{z}=(\mathrm{x}-\mu) / \sigma$, while $x$ is the actual value of the parameter, $\mu$ is the average value and $\sigma$ is the standard deviation for the given parameter. Importantly, the standardization had no effect on the analyses of variance.

a)

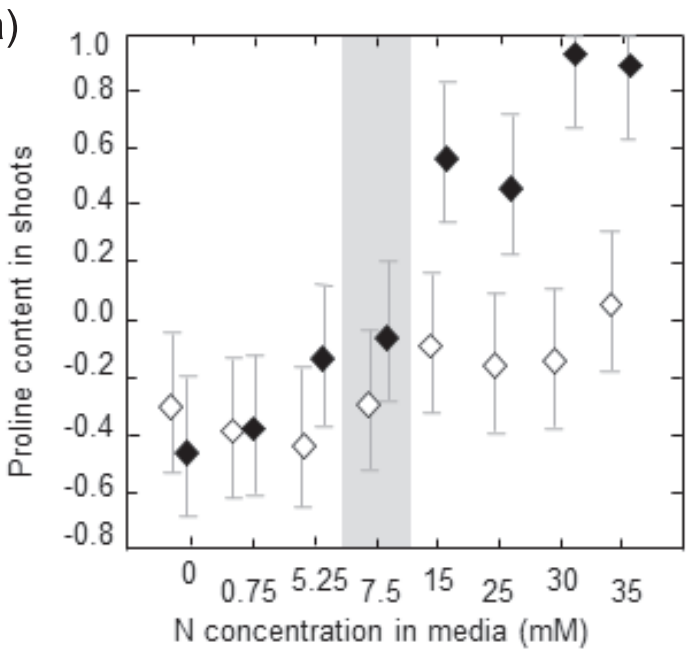

b)

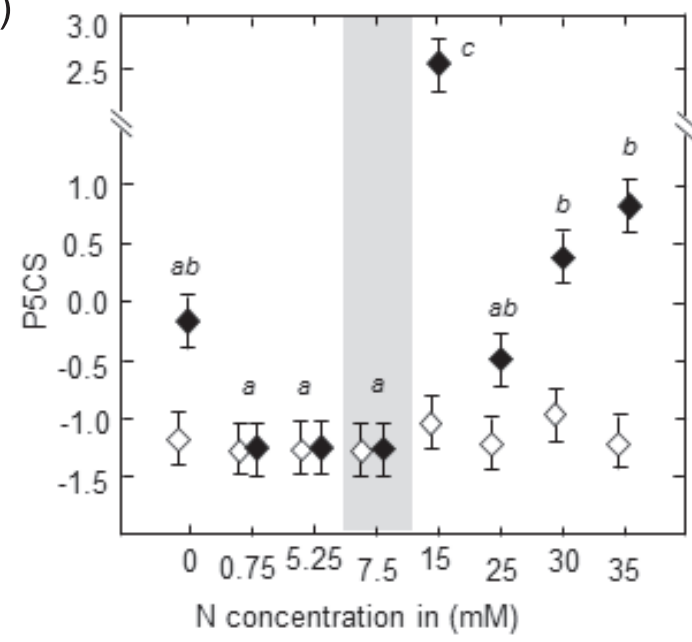

Fig. 2. Impact of different $\mathrm{N}$ concentrations in growth media (0-35 mM) on proline accumulation in leaves of wheat plants grown in hydropony in the absence (empty symbols) or presence (filled symbols) of $5 \mathrm{mM} \mathrm{As}^{3+}$. For total proline content a) the gene for P5CS is likely responsible b), since the gene for the alternative pathway (OAT) was not detected. Standardized data represent average values with $95 \%$ confidential intervals $(n=3)$. Different letters indicate significance at $\mathrm{P}<0.05$. 


\section{Results}

Effect of Different N Concentrations and As Exposure on Wheat Growth and As Accumulation

The $\mathrm{N}$ concentrations in the media affected plant growth (Fig. 1). The length of shoots was the lowest at starving $\mathrm{N}$ condition, the highest at doses close to the optimal $7.5 \mathrm{mM} \mathrm{N}$, and declined again at higher $\mathrm{N}$ concentrations (Fig. 1a). The prolongation of roots did not follow the same pattern (Fig. 1b), indicating a more complex response to higher doses of $\mathrm{N}$. When grown in the presence of arsenic, no additional effects were observed at starving $\mathrm{N}$ doses of 0 and $0.75 \mathrm{mM} \mathrm{N}$ (Fig. 1a and b). At better nutrition, however,

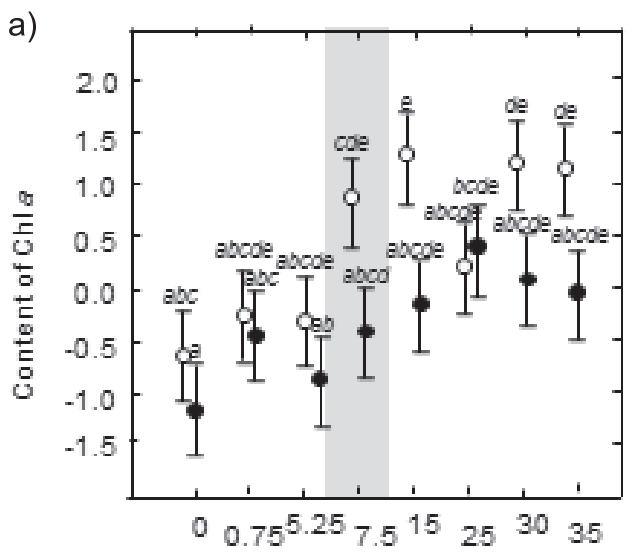

b)

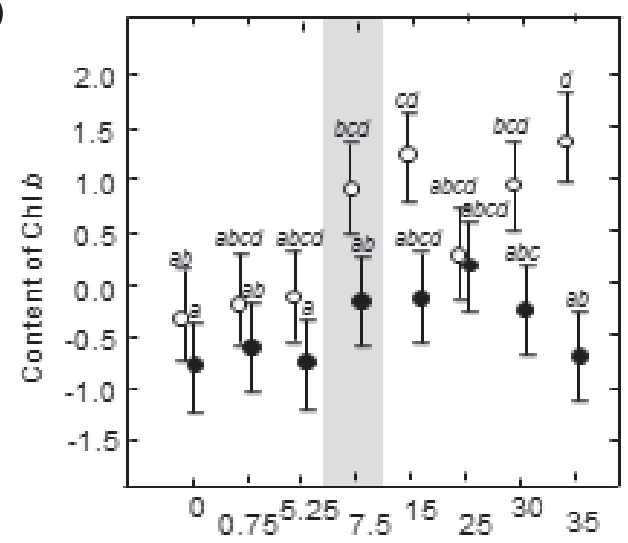

c)

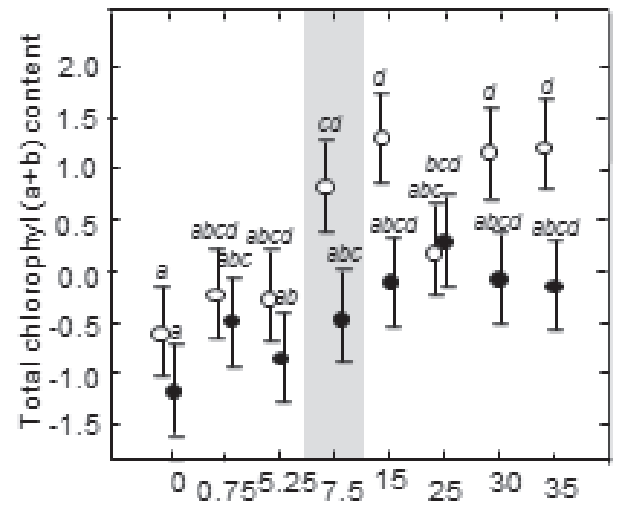

d)

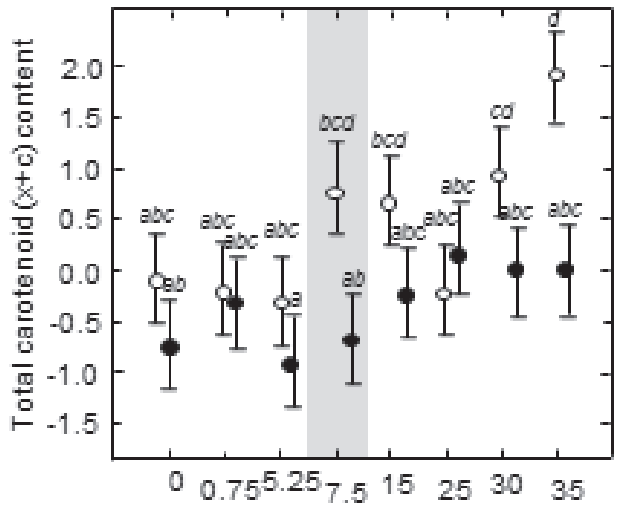

e)

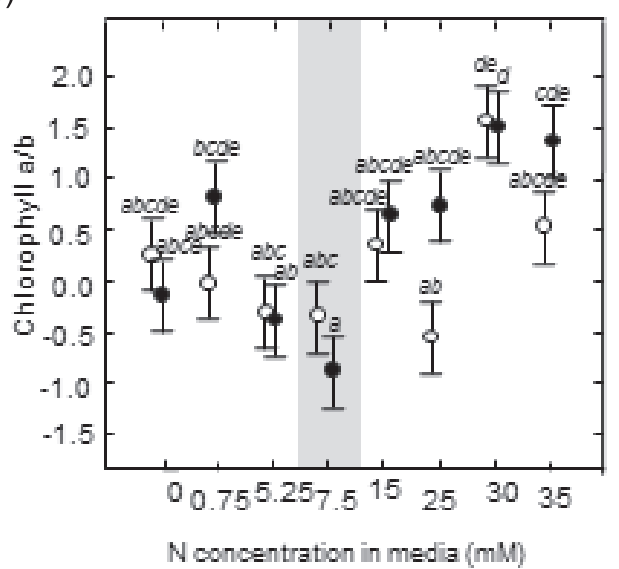

f)

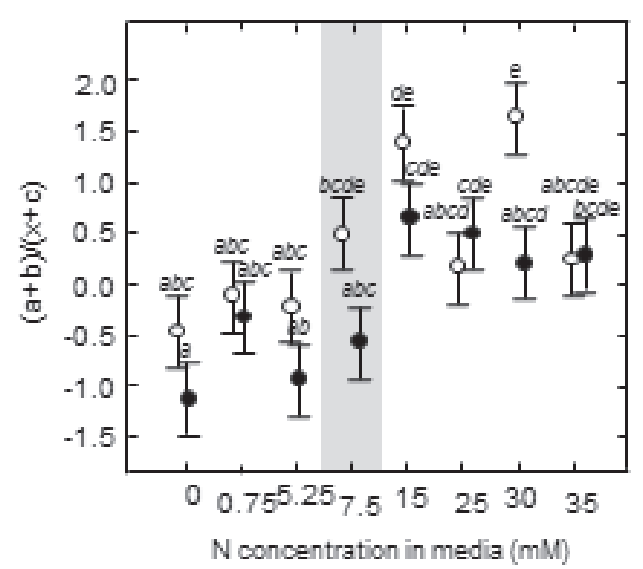

Fig. 3. Impact of different $\mathrm{N}$ concentrations in growth media $(0-35 \mathrm{mM})$ on photosynthetic parameters of wheat plants grown in hydropony in the absence (empty symbols) or presence (filled symbols) of $5 \mathrm{mM} \mathrm{As}^{3+}$. Shown are data for content of chlorophyll a (a), chlorophyl $b$ (b), total chlorophylls $(a+b)(\mathrm{c})$, total carotenoids (d), $\mathrm{Chl} a / \mathrm{Chl} b$ ratio (e), and total $\mathrm{Chl}(a+b) / \mathrm{Car}(\mathrm{f})$. Data in graphs are standardized average values with $95 \%$ confidential intervals $(n=5)$. Different letters indicate significance at $\mathrm{P}<0.05$. 
stunted growth was typical, especially for roots (Fig. 1a and b). While the effect of As was significant on both shoots and roots $(\mathrm{P}<0.001)$, nutrition affected only shoot length $(\mathrm{P}<0.001)$. Nevertheless, the interactive effect of As and $\mathrm{N}$ dose on growth was confirmed for both organ types $(\mathrm{P}<0.05$ in roots; $\mathrm{P}<0.01$ in shoots). The variable nutrition conditions were reflected into accumulated amount of As in shoots that were highest at nutrition conditions close to optimum (Fig. 1c). Despite this, the interplay between the two factors ( $\mathrm{N}$ and $\mathrm{As}$ ) was statistically not supported $(\mathrm{F}=0.82 ; \mathrm{P}=0.577)$.

\section{Oxidative Stress in Response to Different N Concentrations and As Exposure}

Histochemical detection of hydrogen peroxide accumulation indicated ongoing stress in As-treated wheat leaves but not as a consequence of $\mathrm{N}$ concentration alone (Fig. 1e). Quantitation of oxidative stress expressed as MDA level confirmed the effect of As presence at $\mathrm{P}<0.001$. The rate of membrane lipid peroxidation was generally suppressed in metalloid-treated plants, especially at optimal and suboptimal doses of $\mathrm{N}$ (Fig. 1d). Although $\mathrm{N}$ dose also showed a significant effect on MDA levels, $(\mathrm{P}<0.01)$, we did not substantiate the interactive effect of the two parameters in shoots $(\mathrm{P}=0.871)$ (Table 1$)$.

\section{Effects of Different N Concentrations and As Exposure on Proline Content}

Proline, the typical multifunctional plant defense molecule, accumulated in wheat shoot with increasing $\mathrm{N}$ in media $(\mathrm{P}<0.01)$ (Fig. 2). The presence of As further enhanced its accumulation $(\mathrm{P}<0.001)$, but only at higher $\mathrm{N}$ doses in media (Fig. 2a), without demonstrable interaction of the two factors $(\mathrm{P}=0.37)$. Because proline can be synthetized in plants via two pathways (the glutamate and the ornithine pathway), we studied the activity of corresponding key genes - proline synthase $P 5 C S$ and ornithine $\delta$-aminotransferase $O A T$. In the wheat shoots only the P5CS was expressed and strongly induced by two excessive $\mathrm{N}$ doses (15 and $30 \mathrm{mM}$ )
(Fig. 2b), and also by As (both at $\mathrm{P}<0.001$ ). Interactive effect for the two factors also was confirmed $(\mathrm{P}<0.001)$, pointing to complex regulation.

\section{Effects of As on Variable Nutrition on Photosynthetic Pigments}

We measured the contents of photosynthetic pigments in leaves (Fig. 3) as important bioindicators for detecting heavy metal-induced toxicity symptoms in experimental wheat plants. The content of Chl $a$ in wheat leaves gradually increased with increasing $\mathrm{N}$ concentrations in both the absence and presence of As (Fig. 3a). Interestingly, the amounts of both $\mathrm{Chl} b$ and Car appear to follow a similar trend, however, at higher $\mathrm{N}$ concentrations (30-35 $\mathrm{mM}$ ) in the presence of As they significantly dropped (Fig. $3 b$ and d). Further impacts of As were significantly increased ratios of $\mathrm{Chl} a / b$ at doses of 25 and $35 \mathrm{mM} \mathrm{N}$ (Fig. 3e), and the notable drop of the ratio $\mathrm{Chl}(a+b) / \mathrm{Car}$ at 7.5 and $30 \mathrm{mM} \mathrm{N}$ (Fig. 3f). Interaction between the impacts of As and $\mathrm{N}$ doses in wheat shoots was significant only for total carotenoids $(\mathrm{F}=2.66 ; \mathrm{P}<0.05)$ (Table 2).

\section{Discussion}

\section{Effects of As on Wheat Plants}

Arsenic is commonly found in plants, but its concentration under growth in uncontaminated soils rarely exceeds $1.5 \mathrm{mg} \mathrm{kg}$ [19]. Here, the experimental wheat plants grown at optimal conditions $(7.5 \mathrm{mM} \mathrm{N})$ accumulated on average up to $1.3 \mathrm{mg} \mathrm{kg}^{-1}$ As in the aboveground tissue dry mass. The toxicity of the metalloid was manifested in restricted growth of both shoots and roots as observed previously [20-21]. Usually roots are more affected than leaves, being in direct contact with the toxic elements. Previously, heavy metals showed an inhibiting effect on red clover shoots, while no effect on roots has been observed by Mascher et al. [22]. The observed effects, however, can depend on many factors, e.g., plant species or metal type [23 and therein].

Table 2. Effects of arsenic presence (As) and/or nitrate content (N) on photosynthetic pigments.

\begin{tabular}{|c|c|c|c|c|c|c|c|c|c|}
\hline & \multicolumn{3}{|c|}{ Effect of As } & \multicolumn{3}{c|}{ Effect of N } & \multicolumn{3}{c|}{ Effect of N As } \\
\hline Parameter & $\mathrm{F}$ & $\mathrm{D}_{\mathrm{f}}$ & $\mathrm{P}$ & $\mathrm{F}$ & $\mathrm{D}_{\mathrm{f}}$ & $\mathrm{P}$ & $\mathrm{F}$ & $\mathrm{D}_{\mathrm{f}}$ & $\mathrm{P}$ \\
\hline Chlorophyll $a$ & 26,44 & 1 & $<0,001$ & 7,26 & 7 & $<0,001$ & 1,72 & 7 & $=0,115$ \\
\hline Chlorophyll $b$ & 33,39 & 1 & $<0,001$ & 3,44 & 7 & $<0,01$ & 1,87 & 7 & $=0,084$ \\
\hline Total pigments & 31,55 & 1 & $<0,001$ & 7,28 & 7 & $<0,001$ & 1,73 & 7 & $=0,113$ \\
\hline Total carotenoids & 23,85 & 1 & $<0,001$ & 5,25 & 7 & $<0,001$ & 2,66 & 7 & $<0,05$ \\
\hline
\end{tabular}

$\mathrm{F}$ - two-factor dispersion analysis

$\mathrm{D}_{\mathrm{f}}-$ degree of freedom

$\mathrm{P}$ - significance level 
Arsenic-impaired physiology was reflected in the photosynthetic pigment levels (Fig. 3). The results of the present study reveal that applied $\mathrm{As}^{3+}$ concentration ( $5 \mathrm{mM}$ ) decrease the $\mathrm{Chl} a$ content. As the higher plants use this green pigment to run the photochemistry of photosynthesis and produce carbohydrate, As ultimately influences plant growth and yield [14; 24 and therein]. With the exception of the ratio of $\mathrm{Chl} a / b$, each of the studied photosynthetic parameters was significantly influenced by As as observed previously in different plant species [e.g., 21-22, 25-26]. The decrease in the $\mathrm{Chl} a / b$ ratio observed at optimal $\mathrm{N}$ dose indicated that Chl $a$ are more affected than Chl $b$. Previously, Yadav et al. [27] showed that the inhibition in photosynthetic activities by accumulated As may be correlated with substitution of the central atom $(\mathrm{Mg})$ of the chlorophyll molecule by As. Another reason could be a reduction in chlorophyll precursor levels under As exposure and/or reduced chlorophyll biosynthesis [27]. The observed alterations in the Chl $a / b$ ratio after As exposure could also be due to structural changes in the photosynthetic apparatus, i.e., reorganizations of the main pigment-protein complexes, which are reflected in the photosynthetic capacity [28]. Taking into account that this ratio correlates with the amount of the light harvesting complex of PSII (LHCII) and the degree of the membrane stacking [29-30], it could be suggested that $\mathrm{N}$ concentration and As exposure uptake cause changes in the amount of LHCII and the organization of thylakoid membranes.

The biochemical nature of the ongoing changes is explained by the reaction of As with - $\mathrm{SH}$ functional groups of the enzyme $\delta$-ALA dehydratase, which catalyzes the formation of the chlorophyll precursor protochlorophyllid, or by the effect of As on the iron content that is an essential element of chlorophyll precursors [31]. However, As-induced increase of total chlorophylls in pea plants [28] or no effect on carotenoids [32] or Chl $b[26,33]$ have also been observed. As the Car content could be used as reliable criteria for plant tolerance, the obtained alterations in total Car content (anti-stress pigments) in wheat plants suggest that the As-induced toxicity was higher at optimal $(7.5 \mathrm{mM})$ and excessive (35 mM) $\mathrm{N}$ doses (Fig. 3d).

The arsenic-affected leaves accumulated hydrogen peroxide (as we observed in situ), the overall rates of MDA were, however, suppressed. Though metal (and arsenic) stress does evoke oxidative stress in plants [22], a decrease of MDA levels has been observed as well [20], and explained as a superior effect of activated antioxidative defense systems. A total inhibition at this As dose is unlikely. The interaction between the effects of the two stressors (As and N) was not significant (Table 1). Since MDA accumulated at high $\mathrm{N}$ concentration in the presence of As (Fig. 1D), we presume that As triggers lipid peroxidation and disorganizes the membrane structure [34]. Lipid peroxidation in response to As exposure leads to increased ROS production, chloroplast damage, and inhibited chlorophyll biosynthesis, as well as chlorophyll loss, and finally to decreased plant biomass [27]. Activation of defense against As in shoots is reflected in significantly altered proline levels, which is considered a multifunctional defense component under metal stress [35].

\section{Effects of Variable Nutrition on Wheat Responses to As}

In addition to As stress, our experiment included a second, potentially stressful factor. Variable nutrition conditions were defined by a series of $\mathrm{N}$ concentrations in the growth media. Significant impact of nutrition on plants is fully described at both types of extreme values, though the corresponding mechanisms remain unclear. Recently the effect of both lack as well as surplus nitrogen conditions on defense equipment of wheat plants has been demonstrated [14]. It is therefore logical to expect that the presence of the toxic element and the non-optimal nutritional conditions generate a greater impact on the plants. This is especially true if nutritional resources are lacking and the plants have to cope with (multiple) stress by re-modulating the overall metabolism and activating defense. In this context, supra-optimal nutrition sources may be an advantage as they allow for fueling normal processes as well as defense. Accumulating lower amounts of As under higher $\mathrm{N}$ doses seems to support this assumption (Fig. 1c), although a dilution effect due to relatively larger biomass has been excluded [36]. An experimental setup with a broader range of nutritional conditions was expected to bring more light into this question. However, the growth of experimental plants was nonlinear with applied $\mathrm{N}$ doses and tissue type as well as reported previously [14]. In the presence of As, shoots grew relatively best at $\mathrm{N}$ doses close to optimum, but stunting of roots is more serious at higher nitrogen doses (Fig. 1a, b). We suppose this is the result of the combined effect of As toxicity as well as tissue dehydration as excess nitrogen causes water to leach from plants [37].

The content of neither MDA nor proline in wheat shoots showed statistically significant interactive dependence on both nitrogen and As content of the medium. Nevertheless, arsenic caused significant elevation of proline in the shoots at excessive $\mathrm{N}$ doses, likely through the P5CS pathway. The gene for P5CS responded to both As as well as $\mathrm{N}$ concentration, similarly as described in barley exposed to lack on $\mathrm{N}$ and cadmium [38]. The behaviour of this gene supports the recently identified regulation module that coordinates in plants the energetic costs for different processes, including the trade-off between growth and defense [39]. Finkemeier et al. [38] consider such interplay between nitrogen metabolism and depletion of glutathione and phytochelatins as key plant mechanisms during metal stress.

Enhanced tissue proliferation in heavy metal/semistressed tissues has been observed by many authors. 
It is thought to be a reaction to disrupted water balance in tissues due to metal membrane damage, when proline acts as an osmotically active molecule [40]. Proline, however, may also function in the direct protection of the enzyme structure from the effects of metal complexation or as an antioxidant [35]. Siddiqui et al. [41] observed increased proline levels in Withanias omnifera in response to $\mathrm{As}^{3+}$ and $\mathrm{As}^{5+}$ applied at various concentrations. Increased proline levels due to the presence of arsenic has also been documented in other types of plants, including Hydrilla verticillata [42], Vigna mungo [43], and rice [44]. The impact of nutritional conditions on the accumulation of proline in metal stress was, on the contrary, the subject of only a few studies. Konotop et al. [35] detected considerable proline accumulation in soybean plants grown at $30 \mathrm{mM}$ $\mathrm{N}$ in medium and in the presence of $\mathrm{Cd}$, compared to the plants growing at a low dose of nitrogen.

Of the photosynthetic pigments, for antioxidant carotenoids we observed a significant interaction between the effects of metalloid presence and $\mathrm{N}$ availability $(\mathrm{F}=2.66, \mathrm{P}<0.05)$. In general, higher nitrogen availability tends to alleviate the effect of arsenic. Zhang et al. [40] assume that nitrogen in excess acts as a detoxification factor for heavy metal (Cd) stress, since it allows for unblocking the biosynthetic step of converting Urogen ${ }^{3+}$ to Coprogen ${ }^{3+}$ blocked by the metal treatment. However, at extreme doses $(25 \mathrm{mM}$ $\mathrm{N}$ and higher) the $\mathrm{N}$ and the metal(loid) appear to exert joint impacts. Though such concentrations don't occur naturally, the mechanisms and impact of $\mathrm{N}$ on plants alone as well as in combination with other stresses has to be studied further.

\section{Conclusions}

Our research supported the importance of determining optimal fertilizing conditions for plants as both starvation and excess affect photosynthesis negatively. Furthermore, nutrition supply affects the content of photosynthetic pigments in wheat in response to $\mathrm{As}^{3+}$ presence in media. Since the energetic status of plants affected the final As uptake, establishing proper nutrition conditions might be important to limit metal(loid) uptake from soil in contaminated areas. This might be of important relevance not only for metals with toxic effects on biota but also for many microelements that are important for proper plant growth and production.

\section{Acknowledgements}

This work was supported by the bilateral projects APVV-SK-BG-2013-0007 and ДНТ /Slovakia 01/10, 2016 and by the project APVV-15-0051. The authors thank Dr. Pavol Hauptvogel (Gene Bank of the Slovak Republic) for providing wheat seeds.

\section{Conflict of Interest}

The authors declare no conflict of interest.

\section{References}

1. SINGH V.P., SRIVASTAVA P.K., PRASAD S.M. Nitric oxide alleviates arsenic-induced toxic effects in ridged Luffa seedlings. Plant Physiol. Bioch. 71, 155, 2013.

2. TALUKDAR D. Arsenic-induced changes in growth and antioxidant metabolism of fenugreek. Russ. J. Plant Physiol. 60 (5), 652, 2013.

3. UPADHYAYA H., SHIME S., ROY D., BHATTACHARYA $M$. Arsenic induced changes in growth and physiological responses in Vigna radiata seedling: Effect of curcumin interaction. Am. J. Plant Sci. 5, 3609, 2014.

4. TALUKDAR D. Effect of arsenic-induced toxicity on morphological traits of Trigonella foenum-graecum L. and Lathyrus sativus L. during germination and early seedling growth. Curr. Res. J. Biol. Sci. 3 (116-123), 2011.

5. FINNEGAN P.M., CHEN W. Arsenic toxicity: The effects on plant metabolism. Front. Physiol. 3, 182, 2012.

6. CAO Q., HU Q.H., KHAN S., WANG Z.J., LIN A.J., DU X., ZHU Y.G. Wheat phytotoxicity from arsenic and cadmium separately and together in solution culture and in a calcareous soil. J. Hazard. Mater. 148 (1-2), 377, 2007.

7. OTORI K., TANABE N., MARUYAMA T., SATO S., YANAGISAWA S., TAMOI M., SHIGEOKA S. Enhanced photosynthetic capacity increases nitrogen metabolism through the coordinated regulation of carbon and nitrogen assimilation in Arabidopsis thaliana. J. Plant Res. 130 (5), 909, 2017.

8. KONOTOP Y., MÉSZÁROS P., SPIESS N., MISTRÍKOVÁ V., PIRŠELOVÁ B., LIBANTOVÁ J., MORAVČÍKOVÁ J., TARAN N., HAUPTVOGEL P., MATUŠÍKOVÁ I. Defense responses of soybean roots during exposure to cadmium, excess of nitrogen supply and combinations of these stressors. Mol. Biol. Rep. 39 (12), 10077, 2012.

9. DIETRICH R., PLOSS K., HEIL M. Constitutive and induced resistance to pathogens in Arabidopsis thaliana depends on nitrogen supply. Plant Cell Environ. 27 (7), 896, 2004.

10. HUOT B., YAO J., MONTGOMERY B.L., HE S.Y. Growth - defense tradeoffs in plants: a balancing act to optimize fitness. Mol. Plant. 7 (8), 1267, 2014.

11. HAKEEM K.R., CHANDNA R., AHMAD A., QURESHI M.I., IQBAL M. Proteomic analysis for low and high nitrogen-responsive proteins in the leaves of rice genotypes grown at three nitrogen levels. Applied Biochem. Biotech. 168 (4), 834, 2012.

12. CHANDNA R., KAUR G., IQBAL M., KHAN I., AHMAD A. Differential response of wheat genotypes to applied nitrogen: biochemical and molecular analysis. Arch. Agron. Soil Sci. 58, 915, 2012.

13. CHANDNA R., AHMAD A. Nitrogen stress-induced alterations in the leaf proteome of two wheat varieties grown at different nitrogen levels. Physiol. Mol. Biol. Pla. 21 (1), 19, 2015.

14. MAGLOVSKI M., GREGOROVÁ Z., RYBANSKÝ L., MÉSZÁROS P., MORAVČÍKOVÁ J., HAUPTVOGEL P., ADAMEC L., MATUŠÍKOVÁ I. Nutrition supply affects the activity of pathogenesis-related $\beta-1,3-$ glucanases and chitinases in wheat. Plant Growth Regul. 81 (3), 443, 2017. 
15. LICHTENTHALER H., WELLBURN A. Determinations of total carotenoids and chlorophylls $\mathrm{a}$ and $\mathrm{b}$ of leaf extracts in different solvents. Biochem. Soc. T. 11, 591, 1983.

16. THORDAL-CHRISTENSEN H., ZHANG Z., WIE Y., COLLINGE D.B. Subcellular localization of $\mathrm{H}_{2} \mathrm{O}_{2}$ in plants. $\mathrm{H}_{2} \mathrm{O}_{2}$ accumulation in papillae and hypersensitive response during the barley-powdery mildew interaction. Plant J. 11, 1187, 1997.

17. CUI W., CHEN H., ZHU K., Jin Q., XIE Y., CUI J., XIA Y., ZHANG J., SHEN W. Cadmium-induced hydrogen sulfide synthesis is involved in cadmium tolerance in Medicago sativa by reestablishment of reduced (homo) glutathione and reactive oxygen species homeostases. Plos ONE. 9 (10), e109669, 2014.

18. BÉKÉSIOVÁ I., NAP J.P., MLYNÁROVÁ L. Isolation of high quality DNA and RNA from leaves of the carnivorous plant Drosera rotundifolia. Plant Mol. Biol. Rep. 17 (3), 269, 1999.

19. GUPTA D.K., PALMA J.M., CORPAS F.J., 2013. (eds) Heavy metal stress in plants. Springer-Verlag Berlin Heidelberg, Germany.

20. MÉSZÁROS P., RYBANSKÝ L., HAUPTVOGEL P., KUNA R., LIBANTOVÁ J., MORAVČÍKOVÁ J., PIRŠELOVÁ B., TIRPÁKOVÁ A., MATUŠÍKOVÁ I. Cultivar-specific kinetics of chitinase induction in soybean roots during exposure to arsenic. Mol. Biol. Rep. 40 (3), 2127, 2013

21. DOBROVICZKÁ T., PIRŠELOVÁ B., MÉSZÁROS P., BLEHOVÁ A., LIBANTOVÁ J., MORAVČÍKOVÁ J., MATUŠÍKOVÁ I. Effects of cadmium and arsenic ions on content of photosynthetic pigments in the leaves of Glycine $\max ($ L.) Merrill. Pak. J. Bot. 45 (1), 105, 2013.

22. MASCHER R., LIPPMANN B., HOLZINGER S., BERGMANN H. Arsenate toxicity: effects on oxidative stress response molecules and enzymes in red clover plants. Plant Sci. 163 (5), 961, 2002.

23. MOURATO M.P., MOREIRA I.N., LEITÃO I., PINTO F.R., SALES J.R., MARTINS L.L. Effect of heavy metals in plants of the genus Brassica. Int. J. Mol. Sci. 16 (8), 17975, 2015.

24. WANG S., ZHANG D., PAN X. Effects of arsenic on growth and photosystem II (PSII) activity of Microcystis aeruginosa. Ecotox. Environ. Safe. 84, 104, 2012.

25. YILMAZ D.D., TEMIZGÜL A. Assessment of arsenic and selenium concentration with chlorophyll contents of sugar beet (Beta vulgaris var. saccharifera) and wheat (Triticum aestivum) exposed to municipal sewage sludge doses. Water Air Soil Poll. 223 (6), 3057, 2012.

26. MANZANO R., PEÑALOSA J.M., ESTEBAN E. Arsenic accumulation and tolerance of cytisus scoparius under controlled conditions. Water Air Soil Poll. 224 (1), 2013.

27. YADAV G., SRIVASTAVA P.K., PARIHAR P., TIWARI S., PRASAD S.M. Oxygen toxicity and antioxidative responses in arsenic stressed Helianthus annuus L. seedlings against UV-B. J. Photochem. Photobiol. B. 165, $58,2016$.

28. PÄIVÖKE A.E.A., SIMOLA L.K. Arsenate toxicity to Pisum sativum: Mineral nutrients, chlorophyll content, and phytase activity. Ecotox. Environ. Safe. 49 (2), 111, 2001.

29. APOSTOLOVA E.L., DOBRIKOVA A.G., IVANOVA P.I., PETKANCHIN I.B., TANEVA S.G. Relationship between the organization of the PSII supercomplex and the functions of the photosynthetic apparatus. J. Photochem. Photobiol. B: Biology 83 (2), 114, 2006.
30. STOITCHKOVA K., BUSHEVA M., APOSTOLOVA E., ANDREEVA A. Changes in the energy distribution in mutant thylakoid membranes of pea with modified pigment content. II. Changes due to magnesium ions concentration. J. Photoch. Photobio. B. 83 (1), 11, 2006.

31. LEŠKOVÁ A., MOLNÁROVÁ M., FARGAŠOVÁ A. Biochemical view of uptake, metabolism and toxic effects of arsenic compounds on plants. Chem. Listy. 106 (12), 1110, 2012

32. SHAIBUR M.R., KAWAI S. Effect of arsenic on visible symptom and arsenic concentration in hydroponic Japanese mustard spinach. Environ. Exp. Bot. 67 (1), 65, 2009.

33. GUSMAN G.S., OLIVEIRA J.A., FARNESE F.S., CAMBRAIA J. Arsenate and arsenite: The toxic effects on photosynthesis and growth of lettuce plants. Acta Physiol. Plant. 35 (4), 1201, 2013.

34. STOEVA N., BEROVA M., ZLATEV Z. Effect of arsenic on some physiological parameters in bean plants. Biol. Plantarum. 49 (2), 293, 2005.

35. KONOTOP Y., KOVALENKO M., MATUŠÍKOVÁ I., BATSMANOVA L., TARAN N. Proline application triggers temporal red-ox imbalance, but alleviates cadmium stress in wheat seedlings. Pak. J. Bot. 49 (6), 2145, 2017.

36. LANDBERG T., GREGER $\mathrm{M}$. Influence of $\mathrm{N}$ and $\mathrm{N}$ supplementation on $\mathrm{Cd}$ accumulation in wheat grain. Proceedings of the 7th International Conference on the Biochemistry of Trace Elements, Uppsala '03, 2003: Conference Proceedings 1: III, Swedish University of Agricultural Sciences, Uppsala, Sweden, 90.

37. LIU C.W., SUNG Y., CHEN B.C., LAI H.Y. Effects of nitrogen fertilizers on the growth and nitrate content of lettuce (Lactuca sativa L.). Int. J. Environ. Res. He. 11 (4), 4427, 2014.

38. FINKEMEIER I., KLUGE C., METWALLY A., GEORGI M., GROTJOHANN N., DIETZ K.J. Alterations in Cd-induced gene expression under nitrogen deficiency in Hordeum vulgare. Plant Cell Environ. 26 (6), 821, 2003.

39. ZHANG F., WAN X., ZHONG Y. Nitrogen as an important detoxification factor to cadmium stress in poplar plants. J. Plant Interact. 9 (1), 249, 2014.

40. SHARMA S.S., DIETZ K.J. The significance of amino acids and amino acid-derived molecules in plant responses and adaptation to heavy metal stress. J. Exp. Bot. 57 (4), 711, 2006.

41. SIDDIQUI F., TANDON P.K., SRIVASTAVA S. Analysis of arsenic induced physiological and biochemical responses in a medicinal plant, Withania somnifera. Physiol. Mol. Biol. Plants. 21 (1), 61, 2015.

42. SRIVASTAVA S., D'SOUZA S.F. Effect of variable sulfur supply on arsenic tolerance and antioxidant responses in Hydrilla verticillata (L.f.) Royle. Ecotox. Environ. Safe. $\mathbf{7 3}$ (6), 1314, 2010.

43. SRIVASTAVA S., SHARMA Y.K. Arsenic occurrence and accumulation in soil and water of eastern districts of Uttar Pradesh, India. Environ. Monit. Assess. 185 (6), 4995, 2013

44. KUMAR A., DWIVEDI S., SINGH R.P., CHAKRABARTY D., MALLICK S., TRIVEDI P.K., ADHIKARI B., TRIPATHI R.D. Evaluation of amino acid profile in contrasting arsenic accumulating rice genotypes under arsenic stress. Biol. Plantarum. 58 (4), 733, 2014. 